\title{
New Design \& Build Biological System through the Use of Microalgae Addressed to Sustainable Development
}

\author{
Armen B. Avagyan \\ Research and Industry Center of Photosynthesizing Organisms, Feed Additives and Physiologically Active Compounds, Yerevan, \\ Armenia. \\ Email: armin.av@hotmail.com
}

Received January $26^{\text {th }}, 2010$; revised March $16^{\text {th }}, 2010$; accepted March $17^{\text {th }}, 2010$.

\begin{abstract}
Current trends in energy consumption and biofuel manufacturing are neither secure nor sustainable, because they are not provided by necessary cost effective technologies. Further reductions of cost and technological development will be needed for biofuels to be able to compete effectively without subsidy. With the debate raging about raw material of biofuel, microalgae may offer a solution to this conundrum; creating enormous reserves of biofuels and boosting feed production. In this goal Center suggest projects, which incorporate water recourse management and restoration of lakes, freshwater conservation and cleanup through cost effective biodiesel manufacturing as well as pharmaceuticals destruction through the use of microalgae Chlorella and wastewaters aimed to replace the burning technology includes also supplying biofuel profitably and developed pilot bussiness plan based on the cost effective technology through applying new innovative approaches in various stages of microalgae production. The benefits of microalgae are so overwhelming that this, combined with the prospect of the improvement in nature protection, makes it imperative for the world to devise an international response and a plan of action. Incentives will be needed for the development of industry-led platforms such as the World Microalgae Technology Platform and its international financial fund. Microalgae must be the key tool for the new design and building sustainable development and environment management.
\end{abstract}

Keywords: Environmental Management, Microalgae, Algal Bloom, Lake Restoration, Biofuel, Feed Additive, Wastewater Cleaning, Eco-Innovation

\section{Introduction}

A global shadow of environmental deterioration manifests the approaching dangers that threaten the existence of life. Changes in technology drive economic growth in developing countries and contribute significantly to economic well-being in rich countries. While technology has provided yield increases, this has not proved to be sustainable for a long term. Some technological improvements have reduced production risk, while others have increased it. Furthermore, the effects of technological change on production risk have varied taking into account time, space and production activities. Some of these effects have been detrimental to individual and public welfare [1,2]. The patterns of water, nutrients and energy cycles in the biosphere have been established in course of millions of years of biological evolution and thousand of years after the last glace periods. These cycles have been degraded in exponentially accelerating pattern during the last 100 years, by human activities mostly due to the lack of environmental consciousness and mechanistic approach to the management of natural resources. Greater risks of crop failures and livestock deaths are already imposing economic losses and undermining food security, and they are likely to get far more severe as global warming continues [1,2]. In some African countries yields could decline by as much as $50 \%$ by 2020 [3]. Climate change would also lead to increased water stress, which by 2020 could affect 75-250 million people in Africa alone. Our ripening into maturity and survival will depend on our ability to assimilate the explosive progress of technology towards a new culturebioculture-webbed with unifying values and based on the better understanding and respect of the "rights" of bios. Bios provide the unifying force for the harmonious co-existence of all forms of life, leading to a new era of bio-diplomacy. This should provide the opportunity to see the future in a new vision, where technology can serve as a revelation of the truth and where every endeavour is governed by reflection on and appreciation of the environment.

All aspects of infrastructure will be on the rise in 2009, as the governments around the world try to spend their way out of a deep recession. Adaptation measures are 
needed urgently to reduce the adverse impacts of climate change, as well as to minimize the costs of natural disasters. Technological improvements to energy systems drive cause efficiency and hence contribute to climate protection [4]. Cost advantages are the primary drivers for environmentally friendly investments. Approximately $\$ 3.5$ trillion will need to be invested in energy projects in the next 20 years [4]. This corresponds to a six-fold increase from the current level. Planned spending limit on global infrastructure over the next 20 years, including water, transport, energy and healthcare, in total is around $\$ 20$ trillion, but the number of options can make the rollout complex. Acceleration of sustainable development requires the implementation of new innovation measures. The knowledge-based bio-economy will play an important role in our emerging reality. In this case sun microalgae production may be the main future resource for development of Life Industry (food and feed, etc.) and biofuel production as well as for environment management and sustainable development. Therefore this review present situtional analyses and our enviromnent management approch in the framework of our concept addressed to global sustainable development through including microalgae and its biomass in Production (such as wastewater treatment and biofuel) and Bio Cycles (such as food, feed perfumery production etc.) [5]. It will be a key environmental management answer to unsustainable technological developments and Climate Change.

\section{Water Recourse Management}

\subsection{Drinking Water}

Water is a fragile resource that is quite different from, say, ore and oil deposits. It is at once renewable through the natural cycle, yet if spoiled or over-abstracted, it actually becomes non-renewable. Water is unpredictable: even in normally arid regions, floods can cause havoc. Over the last 50 years, global water withdrawal has quadrupled while world population doubled [6]. Currently, about 1 bn people around the world routinely drink unhealthy water. It has been estimated that the number of people worldwide who do not have the access to safe drinking water and sanitation will have risen by 2015 . The global water withdrawal will increase by $31 \%$ between 1995 and 2020. East Asia, Latin America, Africa and several other regions use about one-third as much water per person as the average of OECD countries, and almost one-fifth of what is used in North America. The gravity of the problem increases in the face of global development and large-scale degradation of environment. Increasing pollution loads will outstrip the self-purifying capacity of water systems. If no countermeasures are taken, anthropogenic assault will gradually lead to a situation when water is no longer the source of life, human and ecosystem well-being, but on the contrary, a source of disease, ecosystem disruption and social disorder. Serious decline in water resources has been observed in many parts of the World as a result of the lack of knowledge of how to establish sustainable systems of water management $[7,8]$. Most residents of the US take for granted that we will have an endless supply of water. In order of this view changing the US Department of Health (DOH) says: "Imagine going to your kitchen sink to get a glass of water, and when you turn on the tap nothing is there" [8]. The U.S. Municipal Water Supply -Efficiency Requirements Act and Safe Drinking Water Act directs $\mathrm{DOH}$ to conservation and restoration of drinking water supply. The EU Water Framework Directive requires the "promotion of sustainable water use based on a long-term protection of available water resources" [9].

\subsection{Eutrophication and Algal Bloom}

At present times eutrophication is surely the most important process affecting lakes and water reservoirs worldwide. An important consequence of this process is the general reduction in the possibility of water use and the increasing importance of lakes and reservoirs, consequently, many resources for socio-economic development can be seriously damaged. If aquatic resources are to be exploited on a sustainable basis in the future, a concerted effort is needed to resolve the conflicts between user groups. There is a great need for the restoration of lakes and other natural water bodies as increased nutrient loadings have accrued in the sediments and make it difficult to control the level of fish production. Conservation and restoration of drinking water reservoirs are as well required. The increasing occurrence of harmful algal blooms (HAB) over the last 60 years has been linked to the process caused by the enrichment of water with nutrients from human population growth and associated activity and these problems know no national borders [6-13]. A first priority of US HARRNESS plan for the coming years is to understand and mitigate impacts of $\mathrm{HAB}$ species on pelagic and benthic food webs and their capacity to support fisheries and ecosystem services as well as mitigation of bloom impacts of all types using a suite of practical strategies to protect and utilize threatened resources, as well as to directly intervene in bloom development (where appropriate) using economical and environmentally acceptable methods and mitigate impacts of blue-green algae species on pelagic and benthic food webs and their capacity to support fisheries and ecosystem services $[11,12]$. Blue-green algae of bloom are a group of prokaryotes which history goes back to 2700 million years. Blue-greens are not true algae. They have no nucleus, the structure that encloses the DNA, and no chloroplast, the structure that encloses the photosynthetic membranes, the structures that are evident in photosynthetic true algae. While the simple plants con- 
tinue to thrive, especially in the environments in which they evolved, each new grade of organization has eventually become more "successful" in evolution than its predecessors by most measures. Green algae evolved from prokaryotes between 2500 and 1000 million years ago. Now we see the reverse process, compared to the evolutionary track, that blue-green microalgae become more "successful" in comparison to green algae in water reservoirs as a result of environmental contamination. Management strategies are needed that will prevent (avoid the occurrence of blooms or reduce their extent), mitigate (minimize blue green Cyanobacterial blooms impacts on human health, living resources, and coastal economies when they do occur), and control (actions that directly reduce or suppress an existing bloom population) $[10,11,13,14]$. It is certain that man's contact with bluegreen will increase, and there is a probability that their role in human disease either as toxin sources (neurotoxins affect the nervous system, hepatotoxins - liver, and dermatoxins irritate skin and mucous membranes) or as cutaneous irritants or sensitizers has been underestimated and unsuspected, because the algae blooms are not just disgusting but potentially dangerous [11,12,14-16]. In 1998, the US Environmental Protection Agency (EPA) included freshwater cyanobacteria and their toxins on the first Candidate Contaminant List (CCL) (Federal Register, 1998). The risks humans run by eating fish and other animals from contaminated waters are difficult to quantify but are potentially significant $[11-13,17]$. Concerns about cyanophyte toxins contaminating eggs and carcasses in intensive poultry farms have led to the extensive use of environmentally undesirable pesticides to control blooms in farm water supplies. It is unknown to what extent other algae or cyanophyte toxins may accumulate in agricultural products [14]. There is no such protection in place for the irrigated agriculture and aquaculture industries. We do know that many toxins are extremely persistent in the environment, often being resistant to chemical or bacterial degradation. Preliminary investigations have shown that some toxins persist for more than a week on irrigated pasture grass, spray irrigation may lead to direct contact between water and fruit and it is possible that the toxic cyanophytes will dry on the grape surface. It is unknown which plants actually take up the toxins. However, it is known that some toxins persist in dried form for several months [14]. Currently preventative measures of control against bloom development as well as its toxic forms through preventing of including fertilizers, animal wastes and other sources of nutrients in water resource do not achieve sustainable results and spread of the blue-green infection can reach catastrophic dimension [12]. The conventional treatment and disinfection of most public drinking water supplies are not effective in removing or deactivating cyanophyte toxins as well as boiling is not effective $[14,16]$. Treat- ment techniques have been studied throughout the world and have proved that chlorination is ineffective. Killing the cyanophytes with chlorine, heat, mechanical disrupttion or any other process causes them to lyse and release their endotoxins into the water supply. Water that is free of cyanophytes cells may not be free of the toxins [14]. Now, the most important problem to solve concerns the following question: how to restore and adapt the hydrological, biogeochemical and biological cycles to the new conditions of high population density and activities, without obstructing development [6,9-11]. The first and most obvious step toward protection and restoration of a lake or reservoir is to divert or treat excessive nutrient, organic, and silt loads $[13,14]$. These approaches, however, usually ignore the biological interactions of the lake, interactions which themselves may be responsible for low water transparency, high internal nutrient release, and the frequently observed slow response to nutrient diversion. The new approach requires an understanding of the dynamics of water and biogeochemical processes with special emphasis on the role of biota in the catchment and aquatic systems as being a very vulnerable but easily manageable component of the freshwater ecosystem. Water quality, expressed as secondary pollution and toxic $\mathrm{HAB}$, continues to decline in aquatic ecosystems across the World. Therefore it is possible that problems of algal bloom mitigation can be done not only by reducing human impacts but also by regulating the aquatic biota through biomanipulation. The biomanipulation involves the deliberate alteration of an ecosystem by adding or removing species. Nevertheless, biomanipulation can be used as additional or exclusive measure to improve the quality of stagnant waters $[18,19]$. Food webs are controlled by resource limitation ("bottom-up") and by predation ("top-down"). In the last years, many experiments have been carried on applying gradually of biomanipulation techniques, following a step-by-step procedure aimed to produce a less stressing effect and to have the possibility to modify at any moment the intensity and the direction of the intervention. However, many problems of considerable importance still await a satisfactory solution. It is clear that techniques of integrated biomanipulation show good prospects for managing eutrophic aquatic environments with a view to the ultimate recovery of their quality. The literature on food web manipulation indicates that important factor is the manipulated fish population stability (influences of anthropogenic factor or natural event like fish mortality, etc.). In case of significant change follows fish quantity the new structure might be stable for a short time [14]. Complete removal of the planktivorous fish will not per se lead to optimal conditions for daphnids and stabilize. On the other hand, if the biomass of planktivorous fish exceeds a certain critical level the larger crustacean herbivores will not be able to dominate. Neither phytoplankton densities 
nor biomass quantities can be regulated [20]. The studies dealing with top-down control in the food web have not provided any tailor-made solutions for a reduction of algal bloom biomass and sustainable improvement in light climate. However, the daily feed supply for aquaculture raises nutrient levels, but does not simply increase normal predator-prey activity; rather, HAB events develop often with serious ecological and aesthetic implications [20]. Some typical problems of water quality management through biomanipulation became obvious (blue-green algae, long term stability) [18-20]. Many lakes have extensive littoral areas, and the production of organic matter by these zones is very significant in the cycling of nutrients and in the nutrition of lake organisms. In particular, the large annual production of rooted plants and attached algae may be a major source of decomposing organic matter, and thus nutrients, to the open water and to the sediments of the hypolimnion [13]. Not only are the sediments of the littoral zone the source of nutrients for these rooted plants, the plants may release nutrients to the water column via aerobic decomposition. Even this expensive process, while necessary, may be insufficient to produce immediate and long-lasting effects, due to internal recycling of nutrients and the associated production of algae and macrophytes [13]. The basic assumptions of the biomanipulation concept were found to be generally valid, although quantitatively hard to predict. So studies dealing with biomanipulation tool show that to achieve good prospects and sustainable improvement it is needed provided any tailor-made solutions for a regulation of algal biomass in water resources $[15,18,20]$. Therefore new innovation tool for algal biomass quantity regulation is necessary.

\subsection{Offered Tool for Management in Order to Restore and Conserve Water Recourse}

Our demonstration project of water recourse management includes both supplying energy profitably and restoration of lakes as well as freshwater conservation and cleanup through cost effective biodiesel manufacturing. This technology demonstration and commercialization may be key water quality management effective tool in cost effective manner, because it may be used also for the further biological engineering of the lake system in order to restore biological mechanism that stabilizes the aquatic plant-dominant system, freshwater conservation, cleanup and restoration through reducing negative effect of algal blooms, lake internal surplus nutrient and heavy metals. It will create a more secure environment for power investors and users as well as offered manipulation tools application in biotic dynamics of freshwater ecosystems are synchronous with today's and future world request. Commercialization of the results of our project has the ability of self-start. Consequently, our technological deve- lopment of the microalgae biomass use for biodiesel industry has wide prospects and may provide sustainable economic development and meeting calls of Kyoto Objectives, Environmental Conservation and Lakes and Biodiversity Restoration, FAO, US HAPPINES, World Energy Outlook, World Development Report, 2008; U.S. Presidents Calls, U.S. Resource Conservation and Recovery Act (RCRA, 42 U.S.C. $\$ 6901$ et seq. (1976)), US Safe Drinking Water Act (SDWA, 42 U.S.C. \$300f et seq. (1974)), US Energy Security and Independence Act of 2007 (ESIA), US Department of Energy (DOE) and the US Department of Agriculture (USDA) Biomass Research and Development Initiative (BRDI), Roadmap for Bioenergy and Biobased Products in the US (third generation of biofuel), EU New Energy Policy, EU Renewable Energy Road Map, EU Strategy for Biofuels, European Biofuels Technology Platform, etc. Thus, this technology will promote ecologically friendly solution to restoration and cleanup of lakes and other water reservoirs, conservation of drink water supply, and increasing quantity of valuable biomass for biodiesel manufacturing. On the other hand, EU Environmental Liability Directive (2004/35/EC), seeks to achieve the prevention and remedying of environmental damage, which presents a threat to human health, bringing with it a number of new or increased risks to companies and their director [21]. The Directive has already been implemented in Italy (2006), Spain (2007), France (2008) and England (2009). Therefore this Directive raises the possibility of our technology commercialization in Europe, as it grants a possibility for remedying environmental damage with obtaining profit and decreasing the risk of industries.

\section{Environmental Pollution, Climate Change and Biofuel}

\subsection{Climate Change and Biofuel}

The Kyoto Protocol provides a mechanism for the creation of GHG credits and debits based on limits negotiated for each Annex 1 signatory country to the Kyoto Protocol. Kyoto Protocol came into force on 2005. The World is facing Global Climate Change and twin energy-related threats: that of not having adequate and secure supplies of energy at affordable prices and that of environmental harm caused by consuming too much of it $[22,23]$. Potential interference with the climate system means that proper attention should be paid to the expected evolution of GHG emissions. Global primary energy demand is estimated to increase by just over one-half between now and 2030 - an average annual rate of 1.6\% [22]. Oil demand case will have risen by $29 \mathrm{mb} / \mathrm{d}$ by 2030 , when it will reach $113 \mathrm{mb} / \mathrm{d}$. In the medium-term, by 2012, an average increase of $1.3 \mathrm{mb} / \mathrm{d}$ annually is expected, while this yearly increase gradually falls in the longer term to $1.2 \mathrm{mb} / \mathrm{d}$ p.a [22]. On the other hand global en- 
ergy-related $\mathrm{CO}_{2}$ emissions will have increased by $55 \%$ by 2030 , or by $1.7 \%$ per year. These gases cover a wide range of activities, and include, for example, land-use change and farming. It is important to recall, however, that $\mathrm{CO}_{2}$ emissions from fossil fuel used in 2004 accounted for only $57 \%$ of global GHG emissions. Over $70 \%$ of the increase in demand is observed in developing countries, with China alone constituting 30\%. Developing countries consumption will have almost doubled and reached $56 \mathrm{mb} / \mathrm{d}$ by 2030. Current trends in energy consumption are neither secure nor sustainable economically, environmentally or socially [22,23]. Inexorably rising consumption of fossil fuels and related greenhouse-gas emissions threaten our energy security and risk changing the global climate irreversibly and the US and EU has accelerated the development of renewable energy and reductions in greenhouse gas emissions [22-28].

Biofuel is biodegradable and can reduce vehicle emissions of particulates, carbon monoxide, and hydrocarbons [22]. The benefits of biodiesel include higher lubrication, longer-lasting engines, clean burning as compared to diesel, less reliance on foreign oil, low toxicity, biodegradability, pleasant odour and efficiency as compared to diesel. Compared with using petroleum diesel, the use of biodiesel in a conventional diesel engine substantially reduces emissions of unburned hydrocarbons (HC), carbon monoxide (CO), sulphates, polycyclic aromatic hydrocarbons, nitrated polycyclic aromatic hydrocarbons, and particulate matter (PM). Some PM and HC emissions from diesel fuel combustion are toxic or are suspected of causing cancer and other life threatening illnesses. Using only biodiesel (B100) can eliminate as much as up to $90 \%$ of these "air toxics." B100 provides the best emission reductions, but lower-level blends also provide benefits. B20 has been shown to reduce PM emissions of 10\%, $\mathrm{CO} 11 \%$, and unburned $\mathrm{HC} 21 \%$. Using biodiesel reduces greenhouse gas emissions because $\mathrm{CO}_{2}$ released from biodiesel combustion is offset by the carbon dioxide sequestered while growing the soybeans or other feed stock.

The net impact on greenhouse-gas emissions of replacing conventional fuels with biofuels depends on several factors. These include the type of crop, the amount and type of energy embedded in the fertilizer used to grow the crop and in the water used, emissions from fertilizer production, the resulting crop yield, the energy used in gathering and transporting the feedstock to the biorefinery, alternative land uses, and the energy intensity of the conversion process. Calculating the energy and emissions balance of biofuel production requires estimates of, or assumptions about, all these variables, as well as the energy or emissions credit that should be attributed to the various by-products. $\mathrm{CO}_{2}$ emissions at the point of use are assumed to be zero on the grounds that the biomass feedstock is a renewable resource (the carbon emitted is exactly equal to the carbon absorbed by the bio- mass). In practice, the amount and type of primary energy consumed in producing biofuels and, therefore, the related emissions of greenhouse gases, vary enormously. A study compares several reports on corn-based ethanol production in the US, in order to compile estimates of primary fossil-energy input/output ratios and net greenhouse-gas emissions using consistent parameters. It concludes that the "best point estimate" is that the primary energy input (excluding the biomass feedstock) is equal to about $80 \%$ of the energy contained in the ethanol output. On this basis, greenhouse-gas emissions are only $13 \%$ lower per kilometer compared with petroleum-based fuels [23].

Estimates for the net reduction in greenhouse-gas emissions that are obtained from rapeseed-derived biodiesel in Europe also range from about $40 \%$ to $60 \%$, compared with conventional automotive diesel. The EC shows that conventional ethanol production can result in a net saving of up to $23 \%$ of the fossil energy required for gasoline and a saving of over $30 \%$ in greenhouse-gas emissions. In 2005, biofuels were used in 17 of the 21 Member States of the EU [25]. The EU emitted $5143 \mathrm{Mt}$ of $\mathrm{CO}_{2}$-equivalent in $2006,7.7 \%$ less compared to 1990 levels [24-26]. $\mathrm{CO}_{2}$ intensity, measured as $\mathrm{kgCO}_{2}$ per ton of oil equivalent, has been slowly but steadily declining and in 2006 fell to $2498 \mathrm{kgCO}_{2}$ /toe. Following a period of industrial restructuring in Central and Eastern Europe at the beginning of the 1990s, GHG emissions picked up again after 2000. Carbon-free and indigenous energy sources (renewables and nuclear) in the EU's fuel mix would amount to $28 \%-30 \%$ under the New Energy Policy compared with only $21-25 \%$ under current trends and policies. EU energy industries generated the highest amount of $\mathrm{CO}_{2}$ emissions (37\%) in 2006, followed by transport $(23 \%)$, manufacturing industries and construction $(15 \%)$, and the residential sector $(11 \%)$. EU greenhouse gas emissions from transport have risen considerably since 1990 and are projected to continue increasing [26]. Between 1990 and $2006 \mathrm{CO}_{2}$ emissions from transport increased by $26 \%$. In formulating the future EU energy policy it is necessary to conduct through analysis of possible developments in terms of the EU's energy demand by two main scenarios. In EU New Energy Policy demand in 2020 is projected according to current trends and policies (baseline) and in the case of taking action to achieve agreed EU targets on Climate Change mitigation, namely a reduction of $20 \%$ in greenhouse gas emissions compared to 1990 , along with a $20 \%$ share for renewables in the final energy demand by 2020 , and to bring about a substantial improvement in energy efficiency. In the light of these scenarios, overall developments are described and their impacts on EU energy security and on 2020 objectives are assessed. Under baseline conditions the primary energy needs in 2020 continue to grow, compared to the current situation, although at a lower 
rate than in the past. Given current trends, the EU's consumption rises between $5 \%$ and $9 \%$ depending on the oil price, with the higher increase in the case of moderate oil prices. Gross inland consumption would therefore reach in 2020 a level of between 1,900 and 1,970 Mtoe. Fuel needed for the transport sector remains the main driver. Transport is responsible for more than $50 \%$ of the additional $\mathrm{CO}_{2}$ emissions till 2020. Transport is the only sector that showed an upward trend during this period and its consumption rises by $17 \%-21 \%$ by 2020 , with the lower limit reflecting developments under high oil prices. The share of renewables would increase under all scenarios and price circumstances. However, this increase would be partly nullified by a falling nuclear share as a result of nuclear phase-out decisions and closure of nuclear plants considered unsafe in some Member States as well as sluggish replacement of existing nuclear plants at the end of their lifetime with plants of the same type. Given current policies and trends, irrespective of the level of energy prices, the $20 \%$ target will not be met in 2020. With moderate oil prices, energy-related $\mathrm{CO}_{2}$ emissions are set to rise by 5\% between 1990 and 2020 -back on an ascending path, after earlier reductions due to restructuring in the EU12. GHG emissions would decline by $1.5 \%$ between 1990 and 2020 , due to the reduction in non- $\mathrm{CO}_{2} \mathrm{GHG}$ emissions. Transport accounts for a steadily increasing share of energy-related $\mathrm{CO}_{2}$ emissions under current policies and moderate fuel import prices, reaching $29 \%$ in 2020 compared to $27 \%$ in 2005 and $20 \%$ in 1990 . The $\mathrm{CO}_{2}$ price required to achieve the $20 \%$ reduction in energy-related $\mathrm{CO}_{2}$ emissions would be $€ 41$ per ton of $\mathrm{CO}_{2}$ in 2020 , which is lower than would be the case if no renewables policies were put in place. With high oil prices and a $\mathrm{CO}_{2}$ price equal to $€ 41$ per ton of $\mathrm{CO}_{2}$, energy-related $\mathrm{CO}_{2}$ emissions could be almost $23 \%$ below their 1990 level. This price is consistent with the one that would emerge from the "cost efficient scenario" analyzed in the Impact Assessment for the January 2008 climate and energy package, which does not include JI/CDM credits (JI and CDM contribute to global sustainable development through early mitigation action in third countries, in particular in developing countries [29]). It is however important to bear in mind that the main scenario considered in the January 2008 EC proposal, a policy case which achieves the $\mathrm{CO}_{2}$ and renewables objectives while allowing trade in JI/CDM credits, would result in a lower carbon price of about $€ 30$ per ton $\mathrm{CO}_{2}$ while achieving less energy intensity improvements and $\mathrm{CO}_{2}$ reduction. Implementing the energy and climate policy proposals would improve the environment and diversity of the fuel mix while fostering EU competitiveness through industrial leadership on efficient low carbon technologies.

At present first-generation biofuel technologies, based on grain, sugar and oil crops, will continue to supply the vast bulk of biofuels. The most crucial subject in the debate over the sustainability of biofuels, however, is the impact on the food supply of large-scale use and trade of biomass for energy purposes in case of this generation of biofuels [22,23]. Because biofuels such as biodiesel and bioethanol are made from biomass crops that can also be used for food production, both these markets affect each other. The debate has intensified, particularly, over the impact of biofuels on food prices and their positive effect on the environment. Moreover, the capacity of grainbased first-generation biofuels to replace fossil fuels, particularly for transport, is believed to be extremely limited $[22,23,30]$. The demand for grain will increase further as the world's population grows (9 billion in 2050, compared with 6.5 billion in 2006) and grain consumption in developing countries is expected to have doubled by 2050 from an annual average of 1.1 billion tons between 1999 and 2001 [1]. According to International Monetary Fund rising food and feed demand, which competes with that of biofuels for existing arable and pasture land, will constrain the potential for biofuels production by using current technology [23]. The situation in Japan is a case in point [30]. Japan may face rising food prices and difficulties in securing sufficient amounts of foods, the white paper warned. Seasoning maker Ajinomoto Co said that its fiscal 2006 earnings were weighed down by a spike in sugar cane prices, reflecting the growing popularity of bioethanol as an alternative fuel. Japan should raise its food self-sufficiency rate as the global balance of food supply and demand is expected to get tighter in line with increases in production of biofuels, announced in a Japanese government white paper on agriculture [30]. In the US, more plants have been built for the production of bioethanol leading also to higher prices for food and animal feed [31]. By the use of current technologies demand for corn for biofuel production is expected to have risen to $31 \%$ of the overall US demand for corn in 10 years, from $18 \%$ in 2006, making the amount for export inevitably lower. The International Monetary Fund estimated that higher ethanol production in the US accounted for $60 \%$ of the global increase in corn consumption in 2007 , and that the use of soybean and rapeseed oil in producing biofuels in the EU and US has accounted for the bulk of demand growth for these crops in recent years [22]. This applies especially to densely populated areas where food production has priority over bioenergy production. As an example the US, EU and India have very regulated and protected food markets. There is also no point in developing a first-generation biofuel program if the country has to import expensive chemical fertilizer to increase feedstock production. Very high feedstock prices could also prompt changes in policies regarding subsidies. A further vulnerability is the unpredictability of the weather and its impact on feedstock prices. While a combination of fac- 
tors, including growing demand from emerging countries, lower supply due to unfavourable weather conditions, export bans and market speculation, contribute to food prices rises strong demand for biofuels is also an important reason. Besides the biofuels market, the food market is also a "political" market as it is highly regulated. Thus actual amount of biofuels crop production depends on several actors, political, as well as decisions made at the farming level. Until recently, most biofuels programs were conceived as part of farm-support policies, but a growing number of governments are now planning to expand or introduce such programs for genuine energysecurity, economic and environmental reasons.

The use of agriculture plants for manufacturing of first-generation biofuels could lead also to competition for water resources, both in terms of physical availability and access to water [22,23]. With these biofuels requiring large amounts of water, and with 2050 projections suggesting that irrigation withdrawals may have to increase another $20 \%$ to meet future global food demand, water for biofuels will add pressure to water resources that are already strained or will soon be in many places. The water resource impacts could be large for a number of countries and this is also expected to feed back into global grain markets. A study by the International Water Management Institute concluded that it is unlikely that fast-growing economies such as China and India will be able to meet future food, feed and biofuel demand without substantially aggravating already existing water scarcity problems.

Ultimately, the competition between food and biofuels crop production depends also on land availability [22, 23]. At present about 14 million hectares of land are now used for the production of biofuels, equal to about $1 \%$ of the world's currently available arable land. The amount of arable land needed in 2030 is equal to more than that of France and Spain and that of all the OECD Pacific countries including Australia. Thus land availability and food needs will also limit the growth in conventional biofuels production based on sugar, cereals and seed crops. With pressures on land-use for energy as opposed to food production being increasingly felt around the globe, the growth of biofuels supply-from firstgeneration technologies - is expected to slow sharply in the longer term [23]. Furthermore, until very recently, estimates of GHG emission reductions from biofuels assumed that biofuels are derived from crops grown on lands already in production. Nearly all past life-cycle analyses of the GHG impacts of substituting first-generation biofuels for fossil fuels have ignored emissions resulting from land use change [23]. When land is devoted to biofuels production the carbon stored in trees and bushes will be directly lost, as will a significant portion of the $\mathrm{CO}_{2}$ stored in the soil. These effects can also occur indirectly. For example, the use of a particular crop to produce biofuels in one country may lead to the conversion of grasslands or forest elsewhere to replace that crop. Only lately have attempts been made to quantify emissions from worldwide land use change. A groundbreaking study 18 assessed GHG emissions due to expanding US corn-based ethanol production in 2016 from $1-2 \mathrm{mb} / \mathrm{d}$. The study found that, instead of producing a $20 \%$ reduction in GHGs compared to gasoline, factoring in land change emissions and amortizing them over 30 years roughly doubles GHG emissions [23]. Over time, using corn ethanol would produce GHG benefits, but it would take 167 years to recoup the extra emissions. In other words, corn ethanol production would cause net positive GHG emissions until it had been used for 167 years. Biofuels from switch grass, if grown on the US corn lands, increase emissions by $50 \%$ [23]. Large-scale mono-cropping could have severe negative impacts on biodiversity, soil erosion and nutrient leaching as well as on biodiversity. According to the UN report, even varied and more-sustainable crops grown for energy purposes could have negative environmental impacts if they replace wild forests or grasslands. The United Nations of 2007 report considers 19 problems associated with firstgeneration biofuels among those included in list that will remain the most vexing and deserve the most attention.

\subsection{Enviroment Management and Sustainable Development through including Microalgae and their Biomass in Production and Bio Cycles}

Microalgae contain, among other elements, high quantities of natural proteins, enzymes, amino acids, pigments, $30 \%$ lipids, over $40 \%$ glycerol, up to $8-10 \%$ carotene and a fairly high concentration of vitamins $\mathrm{B}_{1}, \mathrm{~B}_{2}, \mathrm{~B}_{3}, \mathrm{~B}_{6}, \mathrm{~B}_{12}$, $\mathrm{E}, \mathrm{K}, \mathrm{D}$ etc, compared with other plants or animals $[32,33]$. In fact, the former USSR was the first to become a large scale manufacturing of microalgae, in the framework of producing high quality feed additives [33]. In 1980 more than 500 Chlorella manufacturings were in farms of Uzbekistan (mainly for sheep) as well as addiitional quantity in other Soviet republics. However, the disintegration of the USSR has caused interruption of all these manufacturing.

Today's fruits and vegetables contain small amounts of key nutrients, including proteins $(6 \%)$, calcium, phosphorus, iron, vitamin $\mathrm{B}_{2}(38 \%)$ and vitamin $\mathrm{C}$ [34] . Although there is probably more than one explanation, the trend may be largely through farmers choosing to generate a high crop yield. As a result, the need of people and animals to use high quality food and feed additives to compensate for a lack of physiologically active components which they cannot get from ordinary food and feed has increased. During last years, the primary goal was to increase the feed assimilability, but it was achievable principally by using small concentrations of powdered 
activated carbon and adding enzymes, raising only the degree of cellulose hydrolysis, assimilability and the commodity weight of production per feed unit. This one-sided approach has resulted in product quality impairment and a decrease in animal resistance to illnesses. On the other hand, an acute increment of frequency of mass epidemics among animals and poultries in various countries was evidenced. This has caused great economic damage to manufacturers and whole countries. The manufacture of vaccines against mass epidemics requires enormous feats of organization and is not always effective. So, at the end of 2006 a new strain of H5N1 avian flu virus (Fujian-like) was detected in China which was resistant to earlier produced vaccines [33]. Another problem faced today is the consequences caused by the over-use of antibiotics in animal feed. While antibiotics were proven to be effective in improving poultry production, their use came under pressure as an increasing number of consumers feared that their inclusion in animal feed rations would lead to antibiotic resistant bacteria that are pathogenic to humans. In 2005, the EU removed the last antibiotic growth promoters from pig and poultry diets. As consensus begins to develop among the scientific community on this subject, a few approaches stand out in terms of efficacy, technological and economical feasibility, particularly in terms of organic acids and the use of essential or botanical oils. Organic acids provide a natural alternative, reducing production of toxic components by bacteria and causing a change in the morphology of the intestinal wall that reduces colonization of pathogens, thus preventing damage to the epithelial cells [35]. Anions of organic acids deactivate the RNA transferase enzyme, which damage the nucleic acid multiplication process and eventually result in death of the organisms. But the use of organic acids and essential oils in the feed industry are potentially a source of other problems: corrosion, worker safety, handling, vitamin stability in pre-mixes, environmental concerns, and the stability of products [35]. With all this in mind, the use of microalgae Chlorella as a feed additive could become the best solution, since microalgae contain natural organic acids that reduce colonization of pathogens [33]. Thanks to this feature, microalgae Chlorella is used also for feed conservation and reduction of microbiological pollution of wastewaters. Hence, the success of our approach through use of microalgae and its processing products in biofuel manufacturing as feed additives may help reduce not only the general deficiency, but the poor quality and inferiority of the majority of feed additives as well, which may be one of the major causes of the alarming frequency increases of mass epidemics facing animals, poultry, etc. [33].

Second-generation microalgae manufacturing volume sharply increased due to significant influence of food additives, high-quality perfumery related industry development (US, Japan, etc.). So, currently over $75 \%$ of pharmaceutical product development is generated by the food additives production comprising also microalgae. About $61 \%$ of Americans (spending \$ 6 billion yearly) and $43 \%$ of Europeans use food additives. The market survey shows that initially these microalgae manufacturing has reached super high growth rate, sales volume of several companies' has increased doubly, but in condition of the world microalgae manufacturing volume increase the prices of microalgae product was decreasing as well as excess profits gained in companies of developed countries at start up (US Cyanotech. Corp. revenues in million dollars: $1994-2.7 ; 1995-4.2 ; 1996$ 8.1; 1997 - 11.4; 2003 - 9, 2004 - 11.6; 2005 - 11.4; 2008 - 13.9). According to our reseach now Chinese producers have least costs of microalgae manufacturing. At 2004 after start up of bird flu epidemic desicion makers of Chinese and Vietnamese policy felt that feed industry participants should seize the opportunity to grow with the development of livestock and aquacultural production industries. Nowadays Chinese carries out big investments in development of microalgae manufacturing. Taiwan green energy industry set to boom after new law enacted aimed at promoting renewable energy development [36]. The Taiwan Renewable Energy Development Act provides a legal framework that will encourage investment in renewable energy production and offer incentives to local consumers to install renewable energy equipment.

Third-generation microalgae manufacturing volume increase may be caused by biofuel and high quality feed additives productions (microalgae and biofuel manufacturing processing biomass) $[5,32,37]$. Our vision infers suggests that algae have emerged as one of the most promising sources especially for biodiesel. Yields of oil from algae are orders of magnitude higher than those from traditional oilseeds [38,39]. In addition, algae can be grown away in farmlands and forests, thus minimizing the damage caused to the ecosystem and the conventional food chain. Furthermore, algae have properties that make commercial production attractive, such as faster growth compared with land-grown plants; small water consumption, uniform cell structure with no bark, stems, branches or leaves, allowing easier extraction of products and higher utilization of microalgae cells; cellular uniformity making practical the manipulation and control of growing conditions for the optimization of cell properties. Biofuel production will be a new rapidly growing global market for algae products as well as the manufacturing of microalgal biomass may be beneficial to countries not capable of growing conventional crops around the world [32]. Additionally algae can adsorb up to 450 tons of $\mathrm{CO}_{2}$ per acre when grown commercially [40]. They are also harvested very quickly; dramatically speeding up production process with small water consumption [32]. To produce the required amount of biodiesel by growing 
soybeans almost 3 bn acres of soybeans fields, or over $1 \mathrm{bn}$ acres of canola fields at nominal yields of 48 and 127 gallons of oil per acre, respectively, would be required. Conversely, only approximately $9.5 \mathrm{~m}$ acres would be required to produce 15,000 gallons of oil per acre from algae. There is other interesting reason as well: algae can be grown in sewage with its cleaning and next to power-plant smokestacks where they digest the pollutants to produce oil [32,37].

From 1978 to 1996, the U.S. DOE funded a program to develop renewable biodiesel from algae, known as the Aquatic Species Program (ASP, above \$ 300 million) [39, 41]. The main focus of this program was the production of biodiesel from high lipid-content algae. A major conclusion from these analyses is that, for microalgae production, there is little prospect for any alternatives to the open pool designs, given the low cost requirements associated with fuel production. The factors that most influence cost are biological- and not engineering-related. These analyses point to the need for highly productive organisms capable of near-theoretical levels of conversion of sunlight to biomass. Two hundred thousand hectares (less than $0.1 \%$ of climatically suitable land areas in the US) could produce one quad $\left(1.055 \times 10^{18} \mathrm{~J}\right)$ of fuel. The DOE-ASP program concluded that the only plausible near- to mid-term application of microalgae biofuels production requires its integration with wastewater treatment. This would fulfil the main task of ASP and permit the cost-effective technology for microalgae production to be applied around the globe, thus assisting in the resolution of some of the global challenges that face the world community. At 2006-2007 the US researchers and public is abuzz with talk of replacing imported oil with "biofuels" produced from microalgae and as look back at the DOE ASP program [42]. Why would NREL terminate the project if the prospects really were good? During the ASP project appraisal valuable and interesting results of researches have been achieved. However, both the technical and economic conclusions were more poorly given reason, though they coincide with our viewpoints concerning the strategic directions for development of microalgae manufacturing. It is necessary to consider the objective distinctions in an economic situation with fuel today and earlier. In 1998, a barrel of petroleum sold for $\$ 13$ [41]; today the price can exceed $\$ 70-80$ per barrel. In 1982 , it was estimated by Benemann that the cost of production for a barrel of algal biodiesel was, on average of $\$ 94$ (the hypothetical base was \$ 61 and hypothetical high was \$127, depending on the mode of production). According to Michael Briggs: "The operating costs, including power consumption, labour, chemicals, and fixed capital costs (taxes, maintenance, insurance, depreciation, and return on investment) worked out to $\$ 12,000$ per hectare [41]. That would equate to $\$ 46.2$ billion per year for all the algae farms, to yield all the oil feedstock necessary for the entire country. Compare that to the $\$ 100-\$ 150$ billion the US spends each year just on purchasing crude oil from foreign countries, with all of that money leaving the US economy." If the production of algal biodiesel has not already been widespread at an industrial scale, it's simply on account of concerns about profitability and competition and it is necessary, obvious, demonstration large projects. Our research obtained that after terminate ASP program DOE and FP7 R\&D calls attention to microalgae technologies was insufficient. However now many private companies are reviewing their energy policies and strategies to comply by today urgent legislative and economic request and diversification of its business (Table 1).

Table 1. Projects designed to use algae for the production of biofuel

\begin{tabular}{|c|c|}
\hline Company/Institute & Project details \\
\hline $\begin{array}{l}\text { Chevron and National Renewable Energy Laboratory } \\
\text { (NREL) [43] }\end{array}$ & Agreement to investigate the production of liquid transportation fuels from algae. \\
\hline Algae BioFuels (subsidiary of PetroSunDrilling) [44] & Algae cultivation as an energy source for biodiesel in Arizona and Australia. \\
\hline Royal Dutch Shell and HR BioPetroleum [45] & $\begin{array}{l}\text { Venture attempt to build a pilot facility to grow marine algae and produce vegetable } \\
\text { oil for conversion into biofuels. }\end{array}$ \\
\hline Aquaflow Bionomin Co [46] & Mines biodiesel from sewage algae on a lab- and pilot plant-based scale. \\
\hline AlgoDyne Ethanol Energy [47] & $\begin{array}{l}\text { Harvests biomass from marine algal blooms to produce carbon-neutral ethanol, } \\
\text { methanol, biodiesel, electricity, coal and animal feed. }\end{array}$ \\
\hline Maes Anturio Ltd [48] & $\begin{array}{l}\text { Development of an algae filtration system ("Greenbox") that converts } \mathrm{CO}_{2} \text { emis- } \\
\text { sions into biodiesel. }\end{array}$ \\
\hline Solix Biofuels and Colorado State University [49] & $\begin{array}{l}\text { Mass production of cheap algae-derived oil for biodiesel. The alga is grown on } \\
\text { unused land next to power and ethanol plants. }\end{array}$ \\
\hline ExxonMobil and Synthetic Genomics Inc. [SGI] [50] & $\begin{array}{l}\text { Focus is on development of advanced biofuels from photosynthetic algae and ex- } \\
\text { pects to spend more than } \$ 600 \text { million. }\end{array}$ \\
\hline Chinese company ENN [51] & $\begin{array}{l}\text { ENN has launched its pilot scale algal fuels project, gasifying coal underground for } \\
\mathrm{CO}_{2} \text { capture and using the gas as feedstock for algal production and the company } \\
\text { would commence construction of a demonstration-scale plant by late } 2010 \text {, and will } \\
\text { scale to commercial capacities commencing in } 2013 \text {. }\end{array}$ \\
\hline
\end{tabular}


Our market survey shows also that today prices of microalgae products are very high, which can be a result of insufficient investments in the development of innovation technologies. In the last decades our Center strategy believes also that the cost saving of raw material with the use of wastewaters through their biological cleaning will help raise the availability of microalgae biomass for biofuel, food, agriculture, medicinal and producers, thus leading to resolution of global tasks facing the world community. The Center carried out researchers for development technologies of microalgae cultivation in some wastewaters of industrial plants $[32,37]$. As a result the Center developed, in parallel ASP research, a cost effective technology applying new innovative approaches in various stages of microalgae production and this technology for microalgae production may be applied all around the world. Simultaneously the high norms of wastewater purification from organic and mineral compounds were achieved and in parallel to this it was accompanied by sharp reduction of the bacteria contents in strongly microbiological infected wastewater. Presently, our business plan is in the stage of commercialization, both seeking for partners and looking at large-scale production of microalgae in open cement pools to increase the production volume excessively. Our business plan implementation will lead to substantial reduction of financial risks to investor contributions in future microalgae production activity. This is the way, when a cost-effective technology for microalgae production may be used throughout, and microalgae will find their productive application in global markets. Our strategy will allow producing microalgae through the use and purification of wastewaters which may be an additional source of profit, without applying any changes in tax law and subsidizing of biofuel manufacturing and nature protection actions. Consequently, our technological approach development may provide sustainable economic development and meeting Kyoto Objectives, FAO, Energy Outlook, World Development Report, 2008; US Presidents Calls, US Resource Conservation and Recovery Act (RCRA, 42 U.S.C. $\$ 6901$ et seq. (1976)), World Energy Outlook, US Energy Security and Independence Act of 2007 (ESIA), DOE and USDA Biomass Research and Development Initiative, Roadmap for Bioenergy and Biobased Products in the US (third generation of biofuel), EU New Energy Policy, EU Renewable Energy Road Map, EU Strategy for Biofuels, European Biofuels Technology Platform, etc.

Why wastewaters? It is known that the biological method is considered the most effective and economically efficient method for the purification of industrial wastewater by using the microbiological active slime or alga [32,37]. However, bacteria of the active slime have low stability to high concentration of organic and mineral components, thus considering big water flow volumes.
This method also requires further destruction of superfluous quantity of active slime, which contains also pathogenic microorganisms. Microalgae have higher stability, which enables working in more concentrated and toxic environments. Chlorella actively utilizes mineral elements, spirits, sugar, and amino acids and as compared with active slime enables higher purification rate (up to 96$98 \%$ for organic and $80 \%$ for mineral components, accordingly). Chlorella has also organic acids, which prevent the growth of pathogenic microorganisms in wasterwater and feed. While using microalgae, high norms of cleaning were shown for some plants and agriculture wastes. Therefore the use of microalgae for waste and wastewater cleaning open new ways for their cost effective production, environment friendly manufacturing and nature conservation. As an example of this approach, our Center suggests also other demonstration project of drug destruction through the use of microalgae Chlorella and wastewaters aimed to replace the burning technology in order to mitigate Climate Change, environmental pollution and fuel conservation. Why it is necessary? Currently destruction of pharmaceuticals are ideally disposed by their burning at temperature above $1,200^{\circ} \mathrm{C}$ in the special furnaces equipped with filters and in order to prevent the pollution of atmosphere by toxic products of combustion (dioxins and chlorinated dibenzofurans) with $\mathrm{CO}_{2}$ emission. The products of combustion also containing in the stack effluence include $\mathrm{HCl}, \mathrm{CO}, \mathrm{CO}_{2}, \mathrm{NO}_{x}$ etc., causing the pollution of atmosphere by toxic gases, which appear during the start up and burning processes and can't be completely prevented even if the latest technologies of filtration are used. However such incineration facilities, equipped with adequate emission control, are mainly to be found in the industrialized world and this specialized equipment is not available in many countries [52]. During conflicts and natural disasters large quantities of pharmaceuticals are often donated as part of humanitarian assistance and saved as waste [52]. The U.S. Pharmaceuticals Enforcement Administration had given $\$ 50,000$ to Cambodia through the UN for the destruction of 4 tons of pharmaceuticals-making materials found [53]. Quotations for disposing of the pharmaceutical waste in Croatia and Bosnia and Herzegovina in this way range from $\$ 2.2 / \mathrm{kg}$ to $\$ 4.1 / \mathrm{kg}$ [52]. To incinerate the current stockpile of waste pharmaceuticals in Croatia would therefore cost between $\$ 4.4$ and 8.2 million. Only the U.S. HRA charges an annual fee of $\$ 1,000$ for all active studies which covers Auditor/Monitor visits and annual IDS pharmaceuticals storage fees [54]. Furthermore, the U.S. EPA is committed to taking action and working with partners to ensure clean and safe water. The Agency is concerned about the detection of pharmaceuticals and personal care products in U.S. water [55]. At 2008 Judith Enck, Deputy Secretary for the Environment, Office of Governor described pharmaceutical 
waste as an important issue that is a threat to our environment [56]. She believes that there is sufficient evidence to support an immediate end to flushing of unused pharmaceuticals, and charged the group with developing an action plan to address pharmaceuticals in water. The results of the Albany Medical Center Pilot Project program indicate that more than 90 percent of unused pharmaceuticals are unregulated, but those include some of the medications of greatest concern in the U.S. water -antibiotics, antipsychotics, endocrine disruptors, mood elevators, etc [56]. Approximately 5\% of unused pharmaceuticals are controlled substances and 4.4 percent are considered hazardous under RCRA [56]. Therefore the U.S. asked to advice on strategy to develop pharmaceutical take-back program [57]. As a predictable result of the accepted measures by the government of the U.S. (in further may be also other countries), it is possible to expect sharp increase of the pharmaceutical quantity, which is liable to destruction. Hereupon actual task is the development of new cost-beneficial and ecologically safe methods of pharmaceutical destruction. Our developed project provides basic research strategies for destruction of toxic chemicals, decrease of the pharmaceuticals destruction cost and accordingly sales price, mitigation, environmental contamination as well as $\mathrm{CO}_{2}$ emitting, fuel conservation and will allow, in parallel, produce microalgae by the use of wastewater, which obtained biomass may be an additional source of profit through the use for biofuel, feed additives, etc. manufacturing. Consequently, our technological development may provide sustainable economic development and meeting Kyoto Objectives, FAO, U.S. President Calls, U.S. Resource Conservation and Recovery Act (RCRA, 42 U.S.C. $\$ 6901$ et seq. (1976)), U.S. EPA calls, U.S. Energy Security and Independence Act of 2007 (ESIA), U.S. USDA Biomass Research and Development Initiative, Roadmap for Bioenergy and Biobased Products in the U.S. (third generation of biofuel), EU New Energy Policy, EU Renewable Energy Road Map, EU Strategy for Biofuels, European Biofuels Technology Platform, etc.

\section{Where is the General Tool Addressed to Global Environmental Management and Sustainable Development?}

The data shows that today basic cause of the environmental pollution and Climatic Changes is the consequences of the activity of the developed countries, and their outcome effect on all regions around the world. The U.S. and China's combined account is almost half of the planet's carbon emissions [58]. The U.S. government policy highlights the need for the biomass industry to develop new feedstocks that will be easier to grow, produce higher yields of biomass, and be efficiently processed into fuel, power, and products that will help both technology developers and investors identify viable applications of biomass (including alga for third-generation biofuel) for fuels, power or products [27,28]. The U.S. Biomass Research and Development Technical Advisory Committee released its Roadmap lays out a concrete R\&D strategy and recommends policy measures needed to improve biomass technologies and help create an economically viable, sustainable and environmentally desirable biobased industry [27]. USDA and DOE announced that combined, USDA and DOE will invest over three years, for 21 biomass R\&D and demonstration projects [58]. These projects are particularly aimed at overcoming critical barriers in order to make the production of biomass more efficient and cost-effective, in an effort to contribute to the President Administration's strategy of bringing online cleaner, bio-based products and biofuels to help reduce the U.S. dependence on oil from unstable parts of the world and mitigate climate change. The American Recovery and Reinvestment Act, passed by Congress in February this year, provide $\$ 787 \mathrm{bn}$ in appropriations, including $\$ 37.5 \mathrm{bn}$ for energy efficiency and renewable energy [4]. The U.S. has been no government funding for algal research for over a decade [59]. The 6th Annual Renewable Energy Finance Forum - Wall Street will bring together a panel of industry visionaries, financiers and investors to debate key issues and conceptualize the future of renewable energy finance in the U.S. [60,61]. With federal government support and growing confidence among investors, the industry is gearing up to meet this goal despite the challenging economic times. The senior advisor to the Secretary of Energy on the Recovery Act in his keynote speech emphasized the need for the Administration to expedite the allocation of stimulus funding from the DOE, but also expressed the importance of taking a measured approach to the process to ensure a strong foundation so that these projects will be viable in the long term. "This effort is not about the next 1,2 or 3 years - it's about the next 20 years. We need to set up the correct infrastructure to do it right the first time around. Speed and timeliness are important, but we also need to make sure that we are supporting the best projects by administering our programs in the most efficient and effective way possible," he stated: "DOE's goal in the short term is to get private capital off the sidelines and into the game. This means the Department will fund both lower risk mature technologies and higher risk innovative technologies under the Recovery Act. In the longer term, we will return to being an underwriter of higher-risk innovative technologies, plugging holes in areas such as energy efficiency and commercialization scale-up, where private capital markets have traditionally needed more support." One of the main messages that came out of the conference was the assertion that the Administration's goal of doubling investment in renewable energy in the next two years is not only realistic, but necessary, and that the final 
piece of the puzzle for unlocking pent-up private sector investment is the issuance of loan and grant guidance from DOE. ACORE predicts that once the government financing comes into play, it will unlock over $\$ 4$ billion per month in funding for the industry over the next two years. At this summer the DOE said that will make $\$ 85$ million to accelerate commercialization of algae-based and other advanced biofuels [62]. The money is from this Act. According to a report the DOE will pick two or three projects and funds them over three year period. Goal number one is cost competitive algae based biofuels, while objective two is the production of drop-in renewable fuels from other biomass.

The EC will study the possibility of processing cereals from existing intervention stocks into biofuels, finance a campaign to inform farmers and forest operators, bring forward a Forestry Action Plan and examine the possibility of using animal by-products and waste as energy sources. Another aspect of sustainability relates to genetically modified crops and organisms but while biotechnology offers an important approach to improving crop yields, safety in the food chain remains paramount. The policy instruments employed to achieve the GHG reduction target are directly linked with those for the deployment target. The EU Renewable Energy Directive will create conditions enabling renewable energy to play a key role in reaching the GHG reduction target. In its Strategy, the EC defines the role that biofuels, produced from biomass, a renewable resource, may play in the future as a source of renewable energy serving as an alternative to the fossil fuel energy sources (chiefly oil) used in the transport sector $[24,26]$. It also proposes measures to promote the production and use of biofuels. Accordingly, the EU has committed itself to the "2020-20" initiative: reducing greenhouse gas emissions by $20 \%$, increasing the share of renewables in energy consumption to $20 \%$ compared to $8.5 \%$ today and improving energy efficiency by $20 \%$. To put renewals into effect, the EC tabled in January 2008 an integrated proposal for Climate Action aimed at providing a secure and predictable investment climate for EU industry, to which, after eleven months of legislative work, the European Parliament gave its backing Intelligent Energy - Europe II Program [63]. At last, it is essential that the EC continues to support research and innovation, particularly in order to improve production processes and to lower costs. The principal measures will focus on, inter alia, continuing with activities in the field of research and development via the $7^{\text {th }}$ Framework Program for Research and Development and the full use of second-generation biomass and biofuels (i.e. originating from the processing of ligno-cellulosic feedstock such as straw and forest residues).

Hannover Messe's World Energy Dialogue took place in April 2009 with the theme was "Where Future meets
Solutions." The key to success lies in leveraging all available sources and forms of energy towards achieving the correct energy mix. It is also important for these sources to be located in diverse geographic locations and brought together via global grids made possible by innovative technologies and modes of energy transport. Well-balanced, stable trade relations are another pivotal factor, and this hinges on well-wrought foreign policy, intelligent systems of energy supply, advances in energy efficiency, and ongoing energy R\&D aimed at broadening the palette of available alternative. These ideas were discussed and brought to life by various global officials within the energy sectors. According to OECD study, in the EU-25 alone, goods and services provided by eco-industries are estimated to represent around $2.2 \%$ of the EU-25 GDP [64]. EU Eco-innovation under the Competitiveness and Innovation Program (CIP) consists of three components with budget $€ 433$ million (2007-2013) for 37 countries [64].

According to China's National Development and Reform Commission China could generate $20 \%$ of its energy needs from renewable sources by 2020 [65]. Beijing seeks to achieve these goals by directing a significant share of China's \$ 590bn economic stimulus package to low-carbon investment. About understanding of investments significance into innovations testifies carrying out BIT Life Sciences' $1^{\text {st }}$ (Theme: "New Starting Line for Decision Makers in Bio-economy Era") and $2^{\text {nd }}$ (Theme: Innovative Biotechnology for Sustainable Bio-economy) Annual World Congresses of iBio (Beijing 2008, Seoul 2009) by Chinese.

Currently the U.S. and EU's state trade and subsidy policies will be critical to biofuel production. Therefore the burden of subsidy entirely lies upon on their taxpayers. The U.S. support for biodiesel is much more recent compared to that for ethanol. U.S. federal excise-tax credit of $\$ 0.01$ per gallon of crop-based biodiesel for each percentage point share in the fuel blend was introduced in January 2005. Today the U.S. additional tax revenues generated by a profitable biodiesel industry will be significantly larger than the value of the Federal tax incentives provided to the industry. Assuming that the biodiesel tax credit of one cent per gallon for agri-biodiesel and $1 / 2$ cent per gallon for biodiesel from other sources was extended past 2008, the U.S. program would have cost $\$ 3.5$ billion by 2015 . However, as indicated above the industry will generate $\$ 8.3$ billion of new revenue for the Federal Treasury for a positive net balance of $\$ 4.8$ billion. According to the EU Strategy for Biofuel, with the technologies currently available, EU-produced biodiesel breaks even at oil prices around $€$ 60 per barrel, while bioethanol becomes competitive with oil prices of about $€ 90$ per barrel. In compliance with to the Staff Working document adopted together with this Communication, which is based on the JRC Well to 
Wheel analysis, the break even points for biodiesel and for bioethanol are $€ 69-76$ and $€ 63-85$, respectively [25].

Further reductions cost will be needed for biofuels to be able to compete effectively with gasoline and diesel without subsidy [22-24]. According to key players' policy production costs of conventional biofuels are, in general, higher than oil-based fuels, the strong expansion in the biofuel industry over the past few years have been critically dependent upon public sector support programs. Clearly the economics of biofuels are afforded favourable opportunities by these support programs, but it is obvious that the industry has a number of vulnerabilities. For example, while ethanol in the U.S. currently enjoys a price premium as a fuel additive, it is uncertain whether this would continue once the demand for oxygenate is satisfied. Additionally, increasing demand for corn has resulted in higher corn prices, thus narrowing ethanol producers' margins. Very high feedstock prices could also prompt changes in policies regarding subsidies. A further vulnerability is the unpredictability of the weather and its impact on feedstock prices. For example, in North America ethanol production has decreased significantly in the past because corn planting in unusually wet conditions resulted in short corn supplies and higher corn prices. Nevertheless, issues related to land-use changes, competition with the food supply and other biomass uses, biodiversity, and competition for water resources will place a limitation on how much first-generation biofuels can be sustainably produced [23]. Harvesting biomass from forests, if not done properly, can expose soil to drying and erosion, reduce biodiversity, negatively impact the food supply for beneficial insects and woodboring species, reduce organic matter, eliminate habitats and denning sites, and limit flowers that support declining species of pollinators like bees, bats, butterflies and hummingbirds, among other adverse effects [66]. Environmentalists are concerned about tapping into available forest biomass, but officials say it can be done in ways that meet the country's energy needs while maintaining crucial forestlands.

How much is it available? Today the U.S. and EU at first lay their hope mostly on advances second-generation biofuels technologies by the use of forest woody biomass, but significant technological development need to be overcome to make second-generation technologies commercially viable $[22,23]$ and many environmental problems can occur when using forest woody biomass in the global dealer. At present prices of biofuel only increase. Key players of many measures of sustainable development policies are "dangerously optimistic" as, in reality, environment pollution increase [3,67]. Furthermore, the market for greenhouse gases will be worth nearly $\$ 45$ billion by 2010 and only increases (2004- $\$ 0.4$ billion, 2005- 8.72 billion, 2006- $\$ 6.98$ billion; 2007- $\$ 6.68$ billion; 2008- $\$ 12.2$ billion) [68] as well as unfavourable development visualize in algal blooms. On the other hand credit tool of Climate Change shows its small effectiveness, and it is not known - how programs carried in the framework of these credits can compensate the negative effects of environment contamination. A question arises as to how long governments will afford such heavy financial burden aimed to state subsidiary of biofuel producers instead of increasing investments in innovation technologies. The environment recognizes neither ideological nor geographic boundaries, neither developed, nor developing countries. I welcome developed countries' initiatives aimed at mitigating the environmental impact of harmful substances, but it should be noted that such impact has global scale, so the world, as a whole, needs to undertake specific cost effective measures to change the situation. The sustainable development requires global partnerships among all of the countries. Combinations of policies, management approach and resultant actions need to link international processes and national perspectives to local action. It is already clear that the capacity of some communities to adapt will quickly be exceeded if environmental pollution goes globally unmitigated. On the other hand it should be noted that legislative and subsidy policies may not be applied, undoubtedly, in developing and poor countries. Run-time preferences in the implementation of legislative and subsidy policies of industry may weaken companies' competitiveness in world markets and as result technological lag. To help these most vulnerable communities, it is essential for the world to devise a plan of action to technological development. Given the challenge facing us we must produce a multi-lateral agreement that deals adequately with calls of all regions sustainable development. Separate solutions provided on local level cannot have high-performance as we are dealing with a comprehensive biological system. Therefore, the need for taking global action stems from very serious observations also conducted by International Panel for Climate Change (IPCC) [3]. Our vision consist in fact that Global Sustainable Development may be only through development decision in cost effective manner aimed to technologies global partnership of all word players with their synchronous action in area of eco-innovation.

The U.S. agreed in January 2006 to co-operate on the development and transfer of technology to enable greenhouse-gas emissions to be reduced. Under this agreement, known as the Asia-Pacific Partnership on Clean Development and Climate (AP6), member countries are working with private-sector partners in several industry and energy sectors to voluntarily reduce emissions. The sooner a start is made, the quicker a new generation of more efficient and low- or zero-carbon energy systems can be put in place. To this end, they requested the International Energy Agency to "advice on alternative energy scenarios and strategies aimed at clean, clever and 
competitive energy future" [22]. EC also plans to assist developing countries through a specific aid program for biofuels. Its assistance programs aim to promote effective cooperation, including inter alia the development of national biofuel platforms and regional biofuel action plans [24].

The U.S. and EU can play crucial roles in these policy areas, using public spending and grants to create and maintain necessary infrastructure, promote technological innovation and incentivize behavioural change. It is obvious that the budget revenue of the developed countries is insufficient for a global technology transfer and technical support around the word. It is also obvious that the budget revenue of the other countries is insufficient for a technology development or global technology transfer. Therefore, global sustainable development tools must provide incentives to stimulate global investment in eco-innovation projects. Thus, the dilemma faced by policy makers is how to balance the real environmental pollution the need to provide certainty for investors. This offer could be designed in a manner that would simultaneously maintain environmental integrity and minimize risk for investors. Private local investors' attraction of regions required from the key players development policy and institutional decision aimed to financial risks reduction for stimulation of investment attraction in eco-innovation through cost effective market solution, without legislative and business subsidized investment initiatives, which bear heavily on region's local taxpayers.

The Climate Technology Initiative (CTI) held a side event at the UNFCCC, SB30 meetings in Bonn, Germany on 5 June 2009 [69]. The event entitled "Implementing \& Accelerating Technology Transfer for the Transition to a Low Carbon Economy - Lessons from the work of CTI and UNDPA". Asia Forum for Clean Energy Financing (AFCEF) organized and sponsored by CTI and ICETT attracted 60 submissions out of which 11 projects were shortlisted for coaching and showcasing before investors. Mr. Alan Miller, Principal Climate Change Specialist, Climate Change Environment and Social Development Department with the World Bank Group's International Finance Corporation, emphasized the urgent need to redirect private sector investment to clean energy projects in order to achieve the objectives of the UNFCCC. CTI PFAN (Private Financing Advisory Network) is a multilateral initiative organized under the umbrella of CTI with contributions from CTI member countries, USAID, ICETT, APP, and REEEP which offers a free project financing advisory and investment matchmaking service to project developers to help them raise private sector finance that works in many developing markets. PFAN program received endorsement in COP13 decisions (4/CP.13) for its work during the pilot phase, which led to the expansion of the program with new funding from USAID, APP and CTI. CTI's PFAN currently focuses on mitigation projects, but going forward upstream technology development, adaptation projects, and possibly forestry are envisaged for PFAN support. Our research shows that quantity of CTI and PFAN projects are less than needed today. Therefore it is necessary to improve the strategy and development of general lines of environmental management, leading to improved access to financing particularly private capital market to accelerate the broader development and diffusion of environmentally sound technologies.

How long will it take? The world could actually enhance economic output and welfare by pursuing a path of mitigation cost through profitable eco-innovation. If we do not use this way, the negative effects of environment contamination will be difficult to global reverse. Technological improvements will need a better incentive technology to encourage full participation and compliance. Recently, the combination of escalating costs for energy and foods combined with climate change has renewed interest in algae as a clean, carbon neutral energy source. The algal industry needs international and government investment because the initial investments and risks are very high as well as there is not enough quantity of specialists with experience of algae industrial manufacturing management and technology development. Roughly $50 \%$ of Algae World 2008 international conference respondents had less than five years experience in the algal industry while about $16 \%$ with over 20 years of industry experience [59]. Therefore many new studies and contracts between R \& D Centers with private companies are sentenced to repeat past mistakes. The determination to find a solution may have been fueled in part by desperation - and the fact that the world had just been dealt a sobering slap in the face by the financial crisis. That the Copenhagen talks at times seemed like a tussle between the US and China to take the lead in addressing climate change suggests this decade will witness some tremendous geopolitical changes. The countries involved failed come to a binding agreement, but instead signed the Copenhagen Accord., which pledged \$ 30 billion a year to a fund for poor countries to adapt to climate change from $2010-2012$, and $\$ 100$ billion a year by 2020.

\section{Our Vision}

Technological progress and environmental protection are not mutually exclusive, and governments, researches and business communities must mostly focus on emerging technological, procedural, organizational, institutional and political innovations based on the concept of the sustainability around the world. The analysis demonstrates the urgency required for policy and investment action in microalgae manufacturing development. Changes in fuel production, food and agricultural technology drive 
economic growth in developing countries and contribute significantly to economic well-being in rich countries. Identifying opportunities in the next wave of technologies, along with other policy initiatives including financial crisis actions and climate policy, will affect renewable energy companies today and in the future. The gravity of this solution increases in the face of Biofuels Digest updated Advanced Biofuels tracking database, which show that biofuel production capacity now projected to reach 1.704 billion gallons by the end of 2013, based on announced projects and updated company guidance [70]. The database is now tracking 56 companies with advanced biofuels projects in 13 countries. The previous 1.0 release of the database last year had projected production capacity at 1.3 billion gallons. Among algal fuel is projected to reach 421.08 million gallons per year in capacity by 2013 . Therefore including microalgae production by waste and wastewater using in production and bio cycles open new ways for environmentally friendly manufacturing and nature restoration and conservation of nature. Our strategy believes that the cost saving of raw material with the use of wastewaters through their biological cleaning will help raise the availability of microalgae biomass for food, agriculture, medicinal and biofuel producers, thus leading to resolution of global tasks facing the world community. These benefits of microalgae are so overwhelming that this, combined with the prospect of the improvement nature protection, makes it imperative for the world to devise an international response and a plan of action. Incentives will be needed for the development of industry-led plat- forms such as the World Microalgae Technology Platform. It should make it possible to establish a shared World vision and strategy for the production and use of microalgae addressed to biofuels, food and feed additives manufacturing, wastewater cleaning, climate change, etc. as well as the use of financial investments in cost effective manner. The environment management mission of the World Microalgae Technology Platform is to contribute to: the development of cost-competitive eco-innovation through initiatives of the creation, promotion and support regional private Microalgae Research, Technology Development and Demonstration Centers aimed to reduce risk of private investment activities and promote eco-innovation technology transfer around the word. Today the global financial crisis led many foreign investors to seek out conservative investments closer to home rather than in emerging markets [71]. Therefore it is very necessary to develop global network of demonstration projects around the world aimed to promote financial investment and technology transfer. This resolves uncertainties that create difficulties in securing project financing and reduces the cost of measurement, thereby facilitating investment. In practice, technological breakthroughs will almost certainly be needed for Environmental Management. The difficulties in realizing all this in the time frame of our analysis do not justify inaction or delay, which would raise the long-term economic, security and environmental cost. The World Microalgae Technology Platform with its adequate global calls international financial funds can be the key cost-effective tools for global reverse unfavourable change of environ-

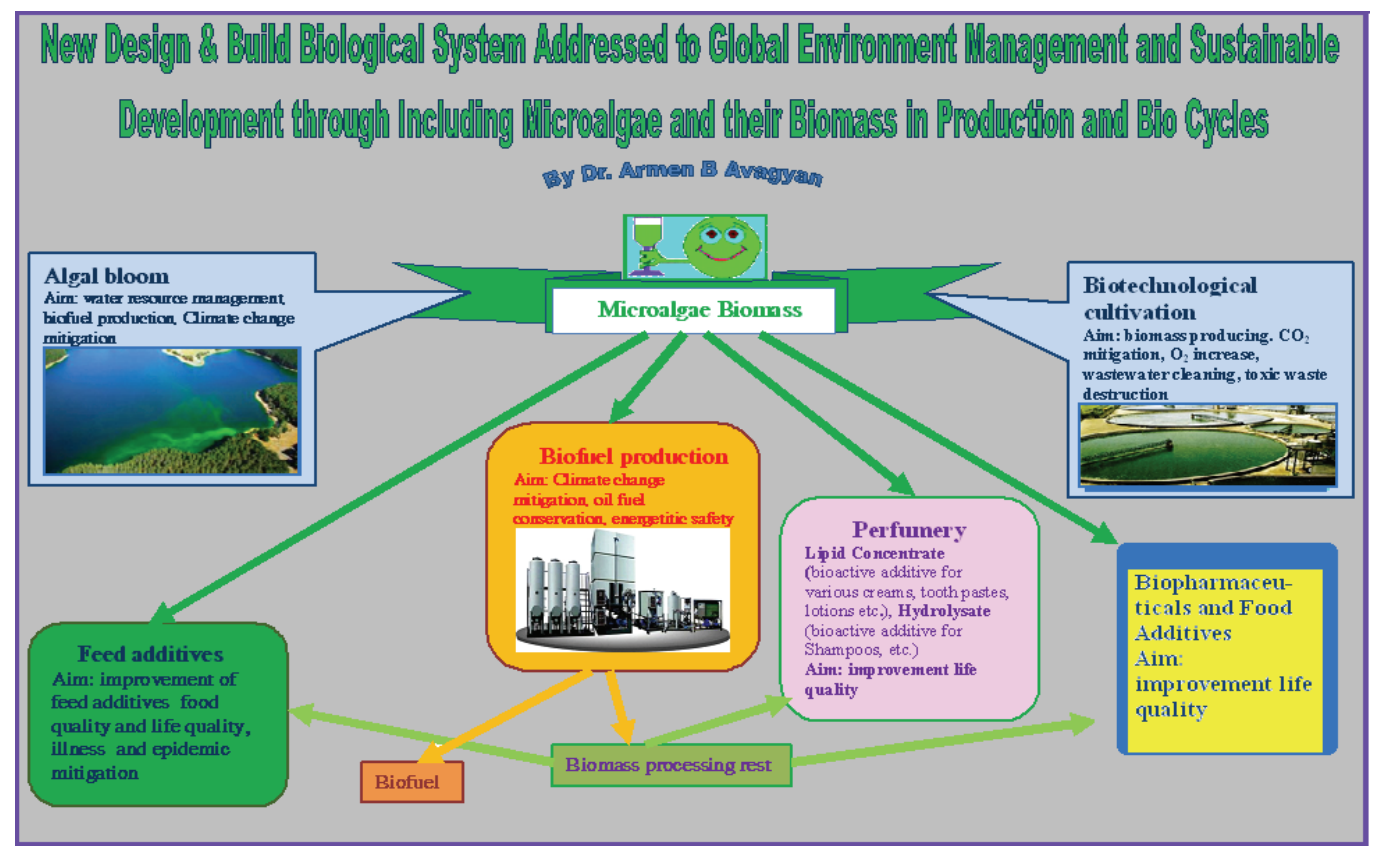

Figure 1. New design \& build biological system addressed to global environment management and sustainable development through including microalgae and their biomass in production and bio cycles 
ment. The piloting innovative finance methods is one of the key priorities in its small-scale project funding, designed to have a "wide ripple effect". Each year of delay in implementing of this environment management tool through the use and commercialization microalgae ecoinnovation would have a disproportionately larger effect on sustainable development. It is possible to expect that in the near future the abovementioned problems will be better perceived, thus leading to global reorientation of global sustainaible development management priorities. This should provide the opportunity to see the future in a new vision, where technology can serve as a revelation of the truth and where every endeavor is governed by reflection on and appreciation of the environment.

Fostering access to microalgae technologies should thus be a key objective for policies aimed at sustainable development, environmental management, drinking water conservation, cleanup and restoration of lakes and mitigation of global climate change as well as for biodiesel, food and feed additives manufacturing etc. In this case sun microalgae production may be the main future resource for development of Life Industry (food and feed, etc.) and biofuel production as well as for environment management and sustainable development (Figure 1).

Microalgae were the key tool for life development on earth; at present algae produce approximately $50-70 \%$ of the atmospheric oxygen and are the World Ocean Water natural cleaner. It is an approved choice of Nature. Therefore microalgae must be the key tool for the new design and building sustainable development of life and environmental management.

\section{REFERENCES}

[1] International Fund for Agricultural Development, 2007. http://www.ifad.org/climate/factsheet/e.pdf

[2] The World Bank, "Adaptation and Mitigation of Climate Change in Agriculture," World Development Report: Agriculture for Development, 2008. http://siteresources. world bank.org/INTWDR2008/Resources/2795087-1192112387 976/WDR08_15_Focus_F.pdf

[3] R. Pachauri, "Where's the World's Plan of Action against Climate Change?" 2009. http:/www.guardian.co.uk/commentisfree/cif-green/2009/jun/23/climate-change-ipcc

[4] G. Platt, "A Bridge to Recovery," Global Finance, Vol. 23, No. 3, 2009, pp. 26-29. http://www.gfmag.com/archives/33-march-2009/706-features-a-bridge-to-recovery. html

[5] A. B. Avagyan, "A Contribution to Global Sustainable Development: Inclusion of Microalgae and their Biomass in Production and Bio Cycles," Clean Technologies and Environmental Policy, Vol. 10, No. 4, 2008, pp. 313-317.

[6] R. J. Clarke, "Water Crisis?" 2003. http://www.oecdobserver. org/news/fullstory.php/aid/935/Water_crisis_html

[7] M. Zalewski, "Ecohydrology. IHP-V Project 2.3/2.4," United Nations Educational, Scientific and Cultural Organization,
McClain, Paris, 1998. http://unesdoc.unesco.org/images/ 0011/001146/114659Eo.pdf

[8] D. A. Clifford, "Water Use Efficiency (WUE) Rule Development," Water Tap, Vol. 21, No. 3, 2005, pp. 10-12. http://www.doh.wa.gov/ehp/dw/Water_Tap/water_tap_ju ne_2005.pdf

[9] European Environment Agency, "Water Resources across Europe-Confronting Water Scarcity and Drought. EEA Report No. 2/2009," March 2009. http://www.eea.europa. eu/publications/water-resources-across-europe

[10] W. J. Cosgrove and F. R. Rijsberman, "World Water Vision: Making Water Everybody's Business," Earthscan Publications, London, 2000. http://www.worldwatercouncil. org/fileadmin/wwc/Library/WWVision/TableOfContents. pdf

[11] J. S. Ramsdell, D. M. Anderson and P. M. Gilbert, "HARRNESS: Harmful Algal Research and Response: A National Environmental Science Strategy 2005-2015," Ecological Society of America, Washington, D.C., 2010, pp. 1-96. http://www.whoi.edu/cms/files/HARRNESS_18189 _23044.pdf

[12] C. B. Lopez, Q. Dortch, E. B. Jewett and D. Garrison, "Scientific Assessment of Marine Harmful Algal Blooms," Interagency Working Group on Harmful Algal Blooms, Hypoxia, and Human Health of the Joint Subcommittee on Ocean Science and Technology, Washington, D.C., 2008. http://ocean.ceq.gov/about/docs/jsost_marine_habs 1208.pdf

[13] Soil and Water Conservation Society of Metro Halifax, "Biological Controls," 2006. http://www.chebucto.ns.ca/ ccn/info/Science/SWCS/biomanip.html

[14] P. Warrington. "Aquatic Pathogens Cyanophytes. The BlueGreen Algae," 2009. http://www.env.gov.bc.ca/wat/wq/ reference/cyanophytes.html

[15] A. Afsar and S. Groves, "Blue-Green Algae Management in Aquaculture," 1995. http://www.phoslock.com.au/newdocs/FRONT\%20PAGE/Blue-Green\%20Algae\%20Mana gement $\% 20 \mathrm{in} \% 20$ Aquaculture.pdf

[16] Soil \& Water Conservation Society of Metro Halifax, "The Blue-Green Algae (Cyanobacteria)," 2007. http://www.chebucto.ns.ca/ccn/info/Science/SWCS/cyano.html

[17] S. Pitos, B. A. Jacson, F. R. C. Path and B. J. B. Wood, "Sources of the Eutrophication Problems Associated with Toxic Algae: An Overview," Journal of Environmental Health, Vol. 64, No. 5, 2001, pp. 25-32. http://www.co.what com.wa.us/health/pdf/water/blue-green-algae-research.pdf

[18] P. Krasprzak, "Objectives of Biomanipulation," in: R. De Bernardi and G. Giusanni, Eds., Guidelines of Lake Management. Biomanipulation in Lakes and Reservoirs Management. UN Environment Program, Vol. 7, 1995, pp. 15-32. http://www.ilec.or.jp/eg/pubs/guideline/Vol.7_Bio manipulation.pdf

[19] P. Kasprzak, J. Benndorf, T. Mehner and R. Koschel, "Biomanipulation of Lake Ecosystems: An Introduction," Freshwater Biology, Vol. 47, No. 12, 2002, pp. 2277-2281.

[20] R. D. Gulati, "Manipulation of Fish Population for Lake Recovery from Eutrophication in the Temperate Region," 
In: R. De Bernardi and G. Giusanni, Eds., Guidelines of Lake Management. Biomanipulation in Lakes and Reservoirs Management, UN Environment Program, Vol. 7, 1995, pp. 53-80. http://www.ilec.or.jp/eg/pubs/guideline/ Vol.7_Biomanipulation.pdf

[21] B. Hilary, "U.K. Companies to Face More Risks under Environmental Directive," Business Insurance Europe, January 2009, p. 2.

[22] International Energy Agency, "World Energy Outlook," 2006. http://www.iea.org/textbase/nppdf/free/2006/weo2006. pdf

[23] Organization of the Petroleum Exporting Countries, "World Oil Outlook," 2008. http://www.opec.org/library/World\% 20Oil\%20Outlook/pdf/WOO2008.pdf

[24] The European Union, “An EU Strategy for Biofuels," Commission Communication, February 2006. http://europa.eu/ scadplus/leg/en/lvb/128175.htm

[25] The European Union, "Report on the Progress Made in the Use of Biofuels and other Renewable Fuels in the Member States of the European Union," Commission Report on Biofuels, January 2007. http://eur-lex.europa.eu/smart api/cgi/sga_doc?smartapi!celexplus!prod!DocNumber\&lg $=$ en\&type_doc $=$ COMfinal\&an_doc $=2006 \&$ nu_doc $=845$

[26] The European Union, “Transport at a Crossroads 2008. TERM 2008: Indicators Tracking Transport and Environment in the European Union," EEA Report No. 3/2009, 2008. http://www.eea.europa.eu/publications/transport-ata-crossroads

[27] Technical Advisory Committee \& Biomass Research and Development Initiative, "Roadmap for Bioenergy and Biobased Products in the United States," Biomass Research and Development, 2007. http://www.biomass.govtools.us

[28] United States Department of Agriculture, "USDA Targeted Incentives for Greenhouse Gas Sequestration," 2003. http://www.usda.gov/news/releases/2003/06/fs-0194.html

[29] European Climate Change Programme Working Group, "ECCP Working Group on JI/CDM Conclusions," November 2002. http://ec.europa.eu/environment/climat/jicdm/ jicdm_final_conclusions.pdf

[30] Global Fuels Staff, "Global Industrial Energy Review," Global Fuels Magazine, February 2007, pp. 11-19.

[31] Efeedlink, "More Ethanol in Gasoline will Mean Higher Meat, Feed Prices in the US," 2009. http://www.efeedlink. com/Membership/dc15eb4f-c423-47b8-9e69-ad8f4bb258 92.html

[32] A. Avagyan, "Global Prospects for Microalgae Production for Biofuels and for the Preservation of Nature," Global Fuel Magazine, February 2008, pp. 22-27. http:// www.propubs.com/global-fuels/eGF_Feb08_LowRes.pdf

[33] A. Avagyan, "Microalgae: Big Feed Potential in a Small Package," Feed International, Vol. 29, No. 2, 2008, pp. 16-18. http://www.fi-digital.com/fi/200803/data/feedinter national200803-win32.zip

[34] D. R. Davis, M. D. Epp and H. D. Riordan, "Changes in USDA Food Composition Data for 43 Garden Crops, 1950 to 1999," Journal of the American College of Nutri- tion, Vol. 23, No. 6, 2004, pp. 669-682.

[35] H. C. Indresh, "Organic Acids, Plant Extracts can be Effective Choice for Antibiotic Alternative," Feed International, Vol. 28, No. 8, 2007, pp. 10-12.

[36] World of Renewables, "Taiwan Green Energy Industry Set to Boom after New Law Enacted," Renewables Toady, Vol. 1, No. 2, 2009. http://www.worldofrenewables.com/ archive/index.php/t-34997.html

[37] A. Avagyan, "Microalgae Production Development Global Prospects and Profitable Technology Wasterwater Purification by the Use Microalgae," Water and Wastewater International, 2008. http://ww.pennnet.com/articles/ article_display.cfm?article_id=340236\&dcmp=WaterWor ldEnl

[38] T. F. Riesing, "Cultivating Algae for Liquid Fuel Production,” 2009. http://oakhavenpc.org/cultivating_algae.htm

[39] J. Sheehan, T. Dunahay, J. Benemann and P. Roessler, "A Look Back at the US Department of Energy's Aquatic Species Program: Biodiesel from Algae," 2006. http://www1. eere.energy.gov/biomass/pdfs/biodiesel_from_algae.pdf

[40] L. Weafer, "Food versus Fuel Debate Continiues to Churn," Feed International, Vol. 29, No. 3, May 2008, p. 6.

[41] O. Danielo, “An Algae-Based Fuel,” Biofutur, No. 255, May 2005. http://www.greenfuelonline.com/gf_files/algae fuel.pdf

[42] "Algae Grow Your Own? Algal Biodiesel: Fact or Fiction?" 2008. http://www.americanscientist.org/template/As setDetail/assetid/53356; http://i-r-www.i-r-squared.blogspot. com/2007/05/algal-biodiesel-fact-or-fiction.html

[43] Chevron Corporation and National Renewable Energy Laboratory, "Chevron Using Algae," 2007. http://www.chev ron.com/news/press/release/?id=2007-10-31; http://www. greencarcongress.com/2007/10/chevron-and-nre.html

[44] J. LeCrone, "Why Algae-to-Biofuels? Why not Now?" 2008. http://biz.yahoo.com/iw/080324/0378475.html

[45] G. Sweeney, "Shell and HR Biopetroleum Form Joint Venture for Algal Biofuel Production," 2007. http://www. greencarcongress.com/2007/12/shell-and-hr-bi.html

[46] Aquaflow Bionomin, 2007. http://www.bio-diesel.co.nz

[47] AlgoDyne, 2007. http://www.algodynecorp.com

[48] Maes Anturio, 2007. http://www.maesanturio.org

[49] Solix Biofuels, 2007. http://www.solixbiofuels.com

[50] ExxonMobil Corporation, "ExxonMobil to Launch Biofuels Program," 2009. http://www.businesswire.com/portal/ site/exxonmobil/index.jsp?ndmViewId=news view\&ndm ConfigId $=1001106 \&$ newsId=20090714005554\&newsLang $=$ en

[51] "Chinese Company Uses Innovative Approach to Make Biofuel," 2009. http://english.ntdtv.com/ntdtv en/ns china/ 2009-10-21/862888436184.html

[52] World Health Organization, "Guidelines for Safe Disposal of Unwanted Pharmaceuticals in and after Emergencies," 1999. http://www.who.int/water_sanitation health/medical waste/unwantpharm.pdf 
[53] M. Veasna and V. O. A. Khmer, "Original Report from Phnom Penh,” 2007. http://ki-media.blogspot.com/2007/05/ us-dea-pledges-50000-for-pharmaceuticals.html

[54] Health Research Association, "Pharmaceuticals Returns \& Destruction," 2009. http://www.health-research.org/files/ pharmacy/PharmaceuticalsReturns.pdf.

[55] Environmental Protection Agency, "Unused Pharmaceuticals in the Health Care Industry: EPA Interim Report," 2008. http://epa.gov/guide/304m/2008/hsi-PRELIM-study200808.pdf

[56] "Proceedings of the Roundtable Discussion on Managing Unused Pharmaceuticals in NYS," 15 May 2008, pp. 1-9. http://www.mass.gov/dep/toxics/stypes/nypharm.pdf

[57] Environmental Protection Agency, "Solving the Pharmaceuticals Disposal Problem through Product Stewardship," 2006. http://www.calpsc.org/assets/ppt/Pharmaceu ticalsDec06fd.ppt

[58] United States Department of Agriculture, "Release No. 0067.08, 2008. http://www.usda.gov/wps/portal/!ut/p/_s. $7 \quad 0 \quad \mathrm{~A} / 7 \quad 0 \quad 1 \mathrm{RD}$ ? printable $=$ true \&contentidonly $=$ true \&co ntentid $=\overline{2008} / 03 / 0067 . x \mathrm{ml}$

[59] M. Edwards, "The Algal Industry Survey," Arizona State University \& Center for Management Technology, Tempe, 2009. http://www.futureenergyevents.com/algae/survey/

[60] REFF-Wall Street, "The 6th Annual Renewable Energy Finance Forum," 2009. http://www.reffwallstreet.com/ima ges/docs/wall\%20st\%208pp\%2009.pdf

[61] "Renewable Energy and Financial Leaders Share Perspectives on Industry Growth Potential." http://www.re newableenergyfocus.com/view/2426/renewable-energy-andfinancial-leaders-share-perspectives-on-industry-growthpotential-/

[62] J. Lane, "DOE Earmarks \$ 85 Million for Algae, Drop-in Biofuels," Biofuel Digest, July 2009. http://biofuelsdigest. com/blog2/2009/07/19/doe-earmearks-85-million-for-alga e-drop-in-biofuels/

[63] Commission of the European Communities, "Intelligent Energy Europe II 2009 Work Programme,” 2009. http://ec. europa.eu/energy/intelligent/call_for_proposals/doc/wp200 9 _en.pdf

[64] European Commission's Environment, "Eco-Innovation: All Innovation, which can Benefit the Environment," 2009. $\mathrm{http}$ ://ec.europa.eu/environment/eco-innovation/what en.htm; http://ec.europa.eu/environment/eco-innovation/docs/call09/ CIP_Eco_innovation_Guide_proposers_2009_FINAL.pdf

[65] J. Borger and J. Watts, "China Launches Green Power Revolution to Catch up on West," The Guardian, 2009. http://www.guardian.co.uk/world/2009/jun/09/china-greenenergy-solar-wind

[66] L. Gibson, "Balancing Act," 2009. http://www.biomass magazine.com/article.jsp?article_id=2814

[67] S. Connor, "Are Greenhouse Gases Causing Climate to Destabilize?" 2004. http://www.ghgx.org/html/news/news archive/GHGs_Destabilizing_climate.pdf

[68] M. Faden, "The Pollution Boom," 2009. http://www.ghgx. org/html/news/news_archive/GHG_emissions_trading.PDF

[69] Climate Technology Initiative, "Implementing \& Accelerating Technology Transfer for the Transition to a Low Carbon Economy - Lessons from the Work of CTI and UNDP," Climate Change Talks, Bonn, 5 June 2009. http:// www.climatetech.net/news/WhatsNew.cfm?Page=1\&News $\mathrm{ID}=56285$; http://www.resourcesaver.com/file/toolmanager/ O105UF1955.pdf

[70] Biofuels Digest, March 2010. http://biofuelsdigest.com/ bdigest/2010/03/02/advanced-biofuels-capacity-will-incre ase-to-1-7-billon-gallons-by-2013-downloadable-database/

[71] G. Platt, "Emerging Markets Focus," Global Finance, Vol. 22, No. 11, December 2008, pp. 39-41. 